\title{
Macrofauna Soil Diversity in Chili Plants (Capsicum Annum L.) With the Use of Organic and Inorganic Mulch
}

\author{
Rumahorbo, D. P.R ${ }^{1}$, Marheni $^{2 *}$, D. Bakti ${ }^{3}$ \\ ${ }^{1,2,3}$ Program Studi Agroteknologi, Universitas Sumatera Utara \\ *marheni@usu.ac.id
}

\begin{abstract}
Chili is one of the vegetable commodities that have great prospects for development, one of which is by increasing the production of chili with organic and inorganic mulch. In addition to increasing the production, mulch can determines macro beneficial soil fauna in crops chili. This Research was conducted on agricultural land, Faculty of Agriculture, USU. This research used Randomized Block Design (RDB) non factorial with 4 treatments (organic mulch, organic mulch + Bacillus Sp., organic Mulch + Bacillus Sp. + Trichoderma, mulch Plastic). This diversity is determined by diversity index assed (ShannonWienner). The results indicated that the macro fauna species caught are the family Salticidae, Formicidae, Gryllidae.
\end{abstract}

Keywords: Chili, organic mulch, inorganic mulch.

\section{Introduction}

Chili is one of the horticultural crops developed in Indonesia, because chili is a horticultural plant that is part of the food culture of Indonesian people. In addition chili also has many benefits for health because the content in it [1]. In an effort to increase the production of red chili plants requires good cultivation techniques, one of which is the use of mulch. Mulch is covering materials into soil around plants to create more beneficial conditions for growth, development and improvement of crop yields. Generally, there are two types of mulch are inorganic and organic mulch. Organic mulch can be a waste of crops such as leaf litter, crop stalks, rice straw, etc. Inorganic mulches are obtained from synthetic materials, for example is the plastic mulch. Effect of mulch applications is determined by the type of mulch material itself [2].

The use of organic mulch will reduce erosion, maintain soil moisture, $\mathrm{pH}$ control, increase drainage, reduces soil compaction, increase ion exchange capacity, and increase soil biological activity [3]. Silver-colored plastic mulch is one component that can be used to control in the disease in chili plants by vector control, controlling several pathogens that are transmitted through soil and grasses, improve quality and yields, and recommended as the one component of integrated pest management [4].

The life of macrofauna in soil is influenced by environmental factors, such as, the factors of micro and macro-environmental factors the soil surface. Micro factors which affect soil 
insects is the thickness of the organic mulch, organic matter content, $\mathrm{pH}$, fertility, soil type, soil density and soil moisture, but macro factors are climate, altitude, types of plants, mulching and land use [5],

The aim of this research to determine the macro diversity of soil fauna on chili plants with organic and inorganic mulch.

\section{Research Method}

\section{a. Time and Place of Research}

The research was conducted in Agricultural Land and multiplication of bacteria symbiont larvae of Oryctes rhinoceros in Disease Laboratory Faculty of Agriculture, University of North Sumatra in April until November 2019.

\section{b. $\quad$ Research Procedures}

Oil palm empty fruit bunches compost with the help of Bacillus Sp. and Trichoderma for 6 weeks. The treatment consisted of four, namely $\mathrm{T} 0=$ organic mulch, $\mathrm{T} 1=$ organic mulch + Bacillus sp., $\mathrm{T} 2=$ organic mulch + Bacillus $\mathrm{sp} .+$ Ttrichoderma, $\mathrm{T} 3=$ plastic mulch. The tools used in this study are pitfall trap by using plastic cups which were applied as many as 4 point made diagonally to the right front, left front, right rear and left rear boundary chili plant canopy.

\section{c. Parameters}

Macrofauna Soil Index Diversity, done by observing the number of insects trapped soil macrofauna, and counted per species populations. The index is used to assess the level of diversity (Shannon-Wienner).

\section{Results and Discussion}

\section{a. Soil macrofauna type}

Based on research conducted at the Faculty of Agriculture of Land North Sumatra on chili plant in April until November 2019 using traps (pitfall trap) gained as much as 44 soil insects macrofauna derived from the phylum Arthropoda. [6] explained that the Arthropod phylum is a land animal groups that generally show the highest dominance among the organisms making up the community land animals. Most species totaling 29 species of 46 species were found to originate from the class Insecta. According to Borror class Insecta is the dominant animal on earth. 
Table 1. Macrofauna soil on chili plant

\begin{tabular}{|c|c|c|c|c|c|c|c|c|c|c|c|}
\hline \multirow[t]{2}{*}{ Ordo } & \multirow[t]{2}{*}{ Family } & \multirow[t]{2}{*}{$\begin{array}{l}\text { Treat- } \\
\text { ment }\end{array}$} & \multicolumn{8}{|c|}{ Week } & \multirow[t]{2}{*}{ Total } \\
\hline & & & I Il & & III & II & $\mathrm{V}$ & VI & VII & VIII & \\
\hline \multirow[t]{4}{*}{ Araenida } & Salticidae & T0 & 1 & 1 & 0 & 0 & 0 & 0 & 0 & 1 & 3 \\
\hline & & $\mathrm{T} 1$ & 1 & 0 & 2 & 0 & 0 & 0 & 0 & 2 & 5 \\
\hline & & $\mathrm{T} 2$ & 1 & 0 & 0 & 1 & 0 & 0 & 1 & 1 & 4 \\
\hline & & $\mathrm{T} 3$ & 0 & 0 & 0 & 0 & 0 & 0 & 0 & 0 & 0 \\
\hline \multirow[t]{4}{*}{ Hymenoptera } & Formicidae & T0 & 1 & 2 & 1 & 0 & 0 & 1 & 0 & 2 & 7 \\
\hline & & $\mathrm{T} 1$ & 2 & 1 & 0 & 0 & 0 & 1 & 0 & 2 & 6 \\
\hline & & $\mathrm{T} 2$ & 1 & 2 & 0 & 0 & 0 & 0 & 2 & 1 & 6 \\
\hline & & $\mathrm{T} 3$ & 0 & 2 & 1 & 1 & 1 & 0 & 0 & 1 & 6 \\
\hline \multirow[t]{5}{*}{ Orthoptera } & Gryllidae & T0 & 0 & 0 & 0 & 0 & 0 & 0 & 1 & 1 & 2 \\
\hline & & $\mathrm{T} 1$ & 0 & 1 & 0 & 1 & 0 & 0 & 1 & 0 & 3 \\
\hline & & $\mathrm{T} 2$ & 0 & 0 & 1 & 0 & 0 & 0 & 0 & 0 & 1 \\
\hline & & $\mathrm{T} 3$ & 1 & 0 & 0 & 0 & 0 & 0 & 0 & 0 & 1 \\
\hline & & & 8 & 9 & 5 & 3 & 1 & 2 & 5 & 11 & 44 \\
\hline
\end{tabular}

namely $\mathrm{T} 0=$ organic mulch, $\mathrm{T} 1=$ organic mulch + Bacillus sp., $\mathrm{T} 2=$ organic mulch + Bacillus sp.

+ Trichoderma, $\mathrm{T} 3$ = plastic mulch.

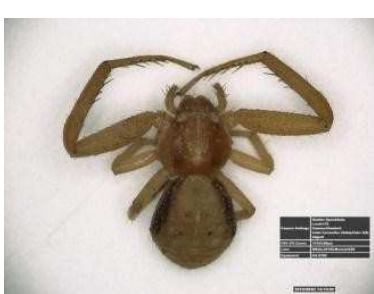

(a)

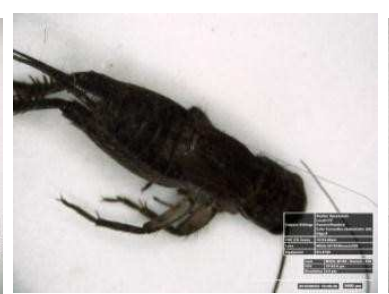

(b)

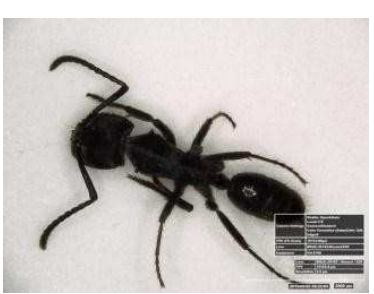

(c)

Fig 1. a. Family Salticidae, b.Famili Gryllidae, c. Family Formicidae

Based on the results of research conducted at the Agricultural Land Agricultural Faculty in Table 1, it is known that this type of macrofauna soil most trapped namely family Formicidae and the lowest of the family gryllidae. It is caused macrofauna soil are mobile depending on the climatic conditions and the environment around planting.

\section{b. Absolute and Relative Density Value}

Absolute density indicates the number of insects found in habitats that are expressed implicitly. Based on research conducted at the Universitas Sumatera Utara Faculty of Agriculture on chili plant in April until November 2019 with the results that the calculation of absolute density and relative density in Table 2. 
Table 2. The value Absolute and Relative Density

\begin{tabular}{|c|c|c|c|c|c|c|c|c|c|c|c|c|}
\hline No & Family & Treatment & \multicolumn{2}{|c|}{$\overline{I \quad I I}$} & III & $\begin{array}{l}\text { IV } \\
\end{array}$ & $\overline{\mathrm{V}}$ & VI & VII & VIII & $\mathbf{K M}$ & KR $(\%)$ \\
\hline \multirow[t]{4}{*}{1} & Salticidae & T0 & 1 & 1 & 0 & 0 & 0 & 0 & 0 & 1 & 3 & 6.82 \\
\hline & & $\mathrm{T} 1$ & 1 & 0 & 2 & 0 & 0 & 0 & 0 & 2 & 5 & 11.36 \\
\hline & & $\mathrm{T} 2$ & 1 & 0 & 0 & 1 & 0 & 0 & 1 & 1 & 4 & 9.10 \\
\hline & & $\mathrm{T} 3$ & 0 & 0 & 0 & 0 & 0 & 0 & 0 & 0 & 0 & 0.00 \\
\hline \multirow[t]{4}{*}{2} & Formicidae & T0 & 1 & 2 & 1 & 0 & 0 & 1 & 0 & 2 & 7 & 15.90 \\
\hline & & $\mathrm{T} 1$ & 2 & 1 & 0 & 0 & 0 & 1 & 0 & 2 & 6 & 13.64 \\
\hline & & $\mathrm{T} 2$ & 1 & 2 & 0 & 0 & 0 & 0 & 2 & 1 & 6 & 13.64 \\
\hline & & $\mathrm{T} 3$ & 0 & 2 & 1 & 1 & 1 & 0 & 0 & 1 & 6 & 13.64 \\
\hline \multirow[t]{5}{*}{3} & Gryllidae & T0 & 0 & 0 & 0 & 0 & 0 & 0 & 1 & 1 & 2 & 4.54 \\
\hline & & $\mathrm{T} 1$ & 0 & 1 & 0 & 1 & 0 & 0 & 1 & 0 & 3 & 6.82 \\
\hline & & $\mathrm{T} 2$ & 0 & 0 & 1 & 0 & 0 & 0 & 0 & 0 & 1 & 2,27 \\
\hline & & $\mathrm{T} 3$ & 1 & 0 & 0 & 0 & 0 & 0 & 0 & 0 & 1 & 2,27 \\
\hline & amount & & 8 & 9 & 5 & 3 & 1 & 2 & 5 & 11 & 44 & 100.00 \\
\hline
\end{tabular}

Based on the results of research was conducted at the Faculty of Agriculture Agricultural Land in Table 2, absolute density and relative density of the highest-dominated family Formicidae T0 with $7 \mathrm{KM}$ and KR is $15.90 \%$, while the lowest for the family Silicide treatment $\mathrm{T} 3$ with $\mathrm{KM} 0$ and $\mathrm{KR}$ is $0 \%$.

Based on the results above, density of macrofauna family is different. Macrofauna types of soil found on the different treatment can be caused due to the soil macrofauna are mobile (moving). When the environmental conditions are not good then the soil macrofauna will change places. The existence of soil fauna is influenced by environmental factors: factors biotic and abiotic factors. Factors which affect abiotic environment are physical factors such as: soil texture, soil structure, and chemical factors include $\mathrm{pH}$, salinity, organic matter and soil mineral. While the biotic factors affected by microflora and plants. Plants can improve soil moisture and as a producer of litter preferred soil fauna [7].

\section{c. Soil Macrofauna Insect Diversity Index}

Macrofauna soil is an indicator that is most sensitive to changes in land use, so it can be used to predict the quality of the land. In carrying out his activities, soil macrofauna need specific requirements. The environmental conditions are the main factors that determine survival. 
Table 3. Shannon Wiener Index ( $\mathrm{H}$ ') soil macrofauna

\begin{tabular}{|c|c|c|c|c|c|c|c|c|c|c|c|c|}
\hline \multirow{2}{*}{ Family } & \multirow{2}{*}{ Treatment- } & \multicolumn{8}{|c|}{ Week } & \multirow{2}{*}{ Total } & \multirow{2}{*}{$\mathbf{P i}$} & \multirow{2}{*}{$\mathbf{H}^{\prime}$} \\
\hline & & $\mathrm{I}$ & II & III & IV & & VI & VII & VIII & & & \\
\hline \multirow[t]{4}{*}{ Salticidae } & T0 & 1 & 1 & 0 & 0 & 0 & 0 & 0 & 1 & 3 & .0681 & .1829 \\
\hline & $\mathrm{T} 1$ & 1 & 0 & 2 & 0 & 0 & 0 & 0 & 2 & 5 & .1136 & .2470 \\
\hline & $\mathrm{T} 2$ & 1 & 0 & 0 & 1 & 0 & 0 & 1 & 1 & 4 & .0909 & .2179 \\
\hline & $\mathrm{T} 3$ & 0 & 0 & 0 & 0 & 0 & 0 & 0 & 0 & 0 & 0 & 0 \\
\hline \multirow[t]{4}{*}{ Formicidae } & T0 & 1 & 2 & 1 & 0 & 0 & 1 & 0 & 2 & 7 & .1590 & .2923 \\
\hline & $\mathrm{T} 1$ & 2 & 1 & 0 & 0 & 0 & 1 & 0 & 2 & 6 & .1363 & .2716 \\
\hline & $\mathrm{T} 2$ & 1 & 2 & 0 & 0 & 0 & 0 & 2 & 1 & 6 & .1363 & .2716 \\
\hline & $\mathrm{T} 3$ & 0 & 2 & 1 & 1 & 1 & 0 & 0 & 1 & 6 & .1363 & .2716 \\
\hline \multirow[t]{4}{*}{ Gryllidae } & T0 & 0 & 0 & 0 & 0 & 0 & 0 & 1 & 1 & 2 & .0454 & .1403 \\
\hline & $\mathrm{T} 1$ & 0 & 1 & 0 & 1 & 0 & 0 & 1 & 0 & 3 & .1681 & .1829 \\
\hline & $\mathrm{T} 2$ & 0 & 0 & 1 & 0 & 0 & 0 & 0 & 0 & 1 & .0227 & .0859 \\
\hline & $\mathrm{T} 3$ & 1 & 0 & 0 & 0 & 0 & 0 & 0 & 0 & 1 & .0227 & .0859 \\
\hline amount & & 8 & 6 & 5 & 3 & 1 & 2 & 5 & 11 & 44 & & 2.032 \\
\hline
\end{tabular}

Based on the results of research conducted at the Faculty of Agriculture in Table 3, insect diversity index of soil in chili with application of organic and inorganic mulches namely 2,032 included in the medium category. This is due to the presence of compounds released by Oil palm empty fruit bunches that are resisting insects. The compound fermented BKS TKS + can also be used as a repellent (insect repellent) for their organic acids are formed. These organic acids are to short-chain hydrocarbons volatile [8].

In the inorganic mulch the soil surface covered by black plastic mulch silver which controls the presence of insects in the crop by using silver mulch ability to reflect sunlight like insects. Silver-colored plastic mulches has the ability to reflect about 33 percent of the sunlight that hits its surface, depending on the amount of dye used and the thickness of the mulch. The reflection of light is able to reduce the heating effect rhizosphere under the plastic surface, and also a range of light favored by insects. So the insects will follow the direction of reflection and leaving crop. So populations of insects, such as aphids and thrips, may be reduced in the zone of crops cultivated [1].

\section{Conclusion}

Type macrofauna found based on the results of research conducted at the Faculty of Agriculture Agricultural Land consists of family Salticidae, Formicidae, Gryllidae. Insect Diversity Index value $\left(\mathrm{H}^{\prime}\right)$ is medium 2.032 . 


\section{References}

[1] Fahrurrozi. Fakta Ilmiah Dibalik Penggunaan Mulsa Plastik Hitam Perak dalam Produksi Tanaman Sayuran. Orasi Ilmiah pada Diesi Natalis \& Wisuda Sarjana I, STIPER Rejang Lebong, Bengkulu. (1994).

[2] Aditya Arif, K. Hendarto, D. Pangaribuan \& K. F. Hidayat. Pengaruh Penggunaan Mulsa Plastik Hitam Perak Dan Jerami Padi Terhadap Pertumbuhan Dan Produksi Tanaman Cabai Merah (Capsicum AnnumL.) Di Dataran Tinggi. Jurnal Agrotek Tropika. (2013).

[3] Subowo, J. Subagja, and M. Sudjadi. Pengaruh Bahan Organik terhadap Pencucian Hara Tanah Ultisol Rangkasbitung Jawa Barat. Pemberitaan Penelitian Tanah dan Pupuk. (1990).

[4] Utama Kadek Dwi, I Gusti Ngurah Bagus,I Ketut Siadi, I Dewa Nyoman Nyana Gede Suastika. Pengaruh Penggunaan Mulsa Plastik Terhadap Kelimpahan Serangga Myzus persicae pada Tanaman Cabai Rawit (Capsicum frutescensL.). Jurnal Agro Tropical. (2015).

[5] Ma'arif samsul, Ni made suartini, I Ketut ginantra. Diversitas Serangga Permukaan Tanah Pada Pertanian Hortikultura Organik Di Banjar Titigalar, Desa Bangli, Kecamatan Baturiti, Kabupaten Tabanan-Bali. Jurnal Biologi XVIII. (2013).

[6] Wallwork, J.B. Ecology of Soil Animals. Mc Graw - Hill. London. (1970).

[7] Endrik Nurrohman, Abdulkadir Rahardjanto, Sri Wahyuni, Keanekaragaman Makrofauna Tanah Di Kawasan Perkebunan Coklat (Theobroma Cacao L.) Sebagai Bioindikator Kesuburan Tanah Dan Sumber Belajar Biologi Keanekaragaman Makrofauna Tanah Di Kawasan Perkebunan Coklat (Theobroma Cacao L.) Sebagai Bioindikator Kesuburan Tanah Dan Sumber Belajar Biologi. Jurnal Pendidikan Indonesia. (2015).

[8] Hoel DF, Kline DL, Allan SA, Grant A. Evaluation of Carbon Dioxide, 1-Octen-3-ol, and Lactic Acid as Baits in Mosquito Magnet TM Pro Traps for Aedes albopictus in North Central Florida. Journal of the American Mosquito Control Association. (2007).

[9] Nusroh, Zaidatun. Studi Diversitas Makrofauna Tanah Di Bawah Beberapa Tanamanpalawija Yang Berbeda Di Lahan Kering Pada Saat Musim Penghujan. Jurnal Penelitian UNS: Surakarta. (2007).

[10] Supriyanti Adik. Perakitan Dan Seleksi Tanaman Cabai (Capsicum AnnumL.) Tahan Cmv (Cucumber Mozaik Virus). Makalah Seminar, Yogyakarta. (2013).

[11] Yanuarti Astri Ridha, M D Afsari. Profil Komoditas Barang Kebutuhan Pokok Dan Barang Penting Komoditas Cabai. (2016). 